\title{
Kinetika Adsorpsi Ion Besi (II) Oleh Biomassa Chaetoceros sp.
}

\author{
Adsorption Kinetic of Ferrous (II) Ion by Chaetoceros sp. Biomass
}

\author{
Paini Sri Widyawati \\ Fakultas Teknologi Pertanian Unika Widya Mandala Surabaya \\ Jl. Dinoyo 42-44 Surabaya Telp.(031) 5678478/Ext 224 E-mail: paini@mail.wima.ac.id
}

\begin{abstract}
This research was done to study the adsorption kinetic of ferrous ionic by Chaetoceros sp. Many variables influenced the adsorption capacity of absorbent on ferrous ionic including interaction time, ferrous ionic concentration and $\mathbf{p H}$. Two absorbens were used in this study i.e. pure culture and natural spoiled product called Diatomite/ Diatomae earth / Diatomaceous earth / Diatomooze of Chaetoceros sp. biomass. The adsorption capacity by biomass was measured by atomic absorption spectrophotometry method (AAS). The result showed that the adsorption process of two absorbents happened very fast. The time needed to get maximal adsorption were 10 and 15 minutes respectively. Adsorption pattern of two biomass can be interpreted by Langmuir and Freundlich isoterm showing monolayer. The adsorption capacity of Diatomite was five times higher than that of the pure culture biomass because it was influenced by surface group charge and wide surface area of porous. Acidity degree (pH) of solution determined surface active group charge and solubility of iron (II). The increased $\mathrm{pH}$ value, the biomass adsorption capacity was added because surface active group had negative charge. The adsorption of biomass was maximal around pH 5 while for pH higher than 5, it wasn't significantly increased because the iron (II) formed insoluble hydroxide compound.
\end{abstract}

Key words: Chaetoceros sp. biomass, adsorption, kinetic, ferrous ion

Diterima: 27 Agustus 2005, disetujui: 02 Agustus 2006

\section{Pendahuluan}

Pencemaran lingkungan perairan, terutama oleh logam seperti $\mathrm{Cd}, \mathrm{Pb}, \mathrm{Hg}, \mathrm{Fe}$, dan $\mathrm{Cu}$ merupakan masalah sangat penting, sebab lingkungan akuatik pendukung utama sistem kehidupan (Ledin et al,. 1997; Nugroho dan Sucahyo, 2000). Akibat pencemaran lingkungan terjadi akumulasi logam dalam ekosistem dan rantai makanan sehingga membahayakan kehidupan akuatik dan penurunan kualitas air (Stary et al., 1983; Slaveykova and Wilkinson. 2002; Stirk and Staden, 2002). Teknologi saat ini telah berhasil meremidiasi logam-logam tersebut melalui proses presipitasi, filtrasi, ion exchange, elektrolisis, proses membran dan evaporasi. Pada dasarnya proses-proses tersebut relatif sangat mahal dan dipengaruhi oleh asam da garam (Aderhold et al., 1996; Hassler et al 2004). Oleh karena itu diperlukan prose penghilangan logam-logam di perairan yan relatif cepat, murah, dan mudah.

Biosorpsi adalah metode yang efisie dan murah untuk menghilangkan ion logan dari larutan dan dapat digunakan untu mengontrol pencemaran oleh industri Biosorpsi biasanya digunakan material yan berasal dari tanaman atau hewan untu mengabsorpsi ion logam. Keterlibatan prose metabolisme menentukan hasil pemantaua pencemaran lingkungan (Stary et al., 1983) Penggunaan biota merupakan metode alternati penanganan pencemaran yang murah untu mengubah dan memperbaiki lingkungan Secara teknik dan komersial penggunaan biot 
dalam menangani masalah lingkungan sangat menarik (Noegrohati dan Narsito, 1990). Proses biosorpsi melibatkan sejumlah mekanisme, seperti: ion exchange, kelating, adsorpsi fisika dan penyerapan ion. Proses sorpsi yang terjadi pada makhluk hidup terjadi secara aktif dan pasif, sedangkan pada makhluk hidup yang mati secara pasif (Stirk and Staden, 2002; Cossich et al., 2001).

Berbagai penelitian telah difokuskan untuk mengidentifikasi kemampuan fitoplankton dalam menurunkan tingkat pencemaran perairan, dengan melibatkan biosorpsi aktif dan pasif (Hamdy, 2000; Nugroho dan Sucahyo, 2000). Penggunaan sel mikroba mati lebih menguntungkan, karena tidak dipengaruhi oleh limbah toksik. Selain itu penggunaan sel mikroba lebih menguntungkan karena tangkapan sel mikroba cepat (antara 0,5 sampai 3 jam), bersifat selektif, faktor biokonsentrasi tinggi (sebesar $10^{4}$ sampai $10^{6}$ ) hal ini terkait dengan luas permukaan yang lebih besar dari volumenya (Harris and Ramelow, 1990; Cossich et al., 2001; Stirk and Staden, 2002;).

Fitoplankton Chaetoceros sp. merupakan ganggang kersik yang tepat digunakan sebagai absorben karena ukurannya yang sangat kecil dengan luas permukaan besar sehingga dapat menangkap ion-ion logam dalam perairan secara cepat dalam waktu yang singkat dan diperoleh faktor konsentrasi yang tinggi (Noegrohati dan Narsito, 1990).

Penelitian ini dilakukan untuk mempelajari kinetika adsorpsi biomassa Chaetoceros sp. yang diperoleh dari kultur murni terhadap ion logam besi (II) serta membandingkan dengan tanah Diatomae yang diperoleh dari proses pembusukan biomassa Chaetoceros sp. secara alami dalam waktu yang lama.

\section{Metode Penelitian}

Biomassa fitoplankton Chaetoceros $\mathrm{sp}$ yang telah mati secara alami melalui proses sedimentasi diperoleh dari lembah Sangiran, yang untuk selanjutnya disebut tanah Diatomae dan biomassa yang diperoleh dari kultur murni fitoplankton di laboratorium melalui proses freeze drying, bibit fitoplankton Chaetoceros sp. diperoleh dari Balai Budidaya Air Payau Jepara.

Bahan kimia yang digunakan meliputi:

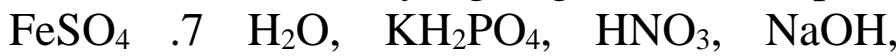
$\mathrm{CH}_{3} \mathrm{COCH}_{3}$, kertas whatmann 42, akuades, kertas $\mathrm{pH}$ universal, $\mathrm{FeCl}_{3}, \mathrm{EDTA}, \mathrm{KNO}_{3}$, $\mathrm{NaH}_{2} \mathrm{PO}_{4}, \mathrm{Na}_{2} \mathrm{SiO}_{3}$, dan Vitamin $\mathrm{B}_{12}$.

\section{Penetapan lama adsorpsi ion besi (II) pada biomassa Chaetoceros sp.}

Biomassa seberat $15 \mathrm{mg}$ ditambahkan dengan $10 \mathrm{ml}$ larutan besi (II) 10 ppm, interaksi antara kedua campuran tersebut dilakukan dengan waktu secara berturutan sebagai berikut: 5, 10, 15, 30 dan 60 menit, selanjutnya campuran disaring dengan funnel untuk memperoleh filtrat. Konsentrasi ion besi (II) dalam filtrat yang diperoleh dianalisis dengan metode spektrofotometri serapan atom dengan menggunakan kurva standar, konsentrasi yang terukur sebagai konsentrasi ion besi (II) yang tidak teradsorpsi atau keseimbangan. Selanjutnya dilakukan perbandingan lama adsorpsi ion besi (II) pada biomassa hasil kultur dan tanah diatomae.

\section{Penetapan kemampuan adsorpsi biomassa Chaetoceros sp. pada berbagai konsentrasi ion besi (II)}

Biomassa seberat $25 \mathrm{mg}$ ditambahkan secara berturutan $10 \mathrm{ml}$ larutan besi (II) dengan konsentrasi secara berturutan sebagai berikut: 1, 3, 5, 10, 15, 30 dan 50 ppm, interaksi antara biomassa dengan larutan besi (II) dilakukan dengan lama interaksi disesuaikan dengan data yang diperoleh pada percobaan penetapan lama adsorpsi ion besi (II) (waktu adsorpsi maksimum). Selanjutnya konsentrasi ion besi (II) dalam filtrat ditentukan sesuai dengan percobaan sebelumnya.

\section{Penetapan kemampuan adsorpsi biomassa Chaetoceros sp. terhadap ion besi (II) pada berbagai variasi $\mathbf{p H}$}

Biomassa Chaetoceros sp. seberat $25 \mathrm{mg}$ ditambahkan $10 \mathrm{ml}$ larutan ion besi (II) dengan konsentrasi secara berturutan sebagai berikut : 2, 6 dan 10 ppm untuk masing-masing $\mathrm{pH}$ yaitu $0,5,1,2,2,5,3,5,4,4,5,5,5,5,7,10$, 
selanjutnya dengan cara yang sama seperti percobaan sebelumnya ditentukan konsentrasi ion besi (II) dalam filtrat.

\section{Analisis Data}

Data yang diperoleh pada percobaan digunakan untuk menentukan konsentrasi ion besi (II) yang dapat terabsorpsi pada biomassa Chaetoceros sp. Konsentrasi ion besi (II) yang teradsorpsi dapat dihitung dengan menggunakan persamaan sebagai berikut (Thakur, 2001):

$$
\mathrm{Ct}=\mathrm{Ca}-\mathrm{Ctt}
$$

Keterangan:

$\mathrm{Ct}=$ konsentrasi ion besi (II) teradsorpsi

$\mathrm{Ca}=$ konsentrasi ion besi (II) awal

$\mathrm{Ctt}=$ konsentrasi ion besi (II) tidak teradsorpsi

\section{Hasil dan Pembahasan}

Akumulasi ion logam dalam biomassa biota perairan dapat berlangsung melalui berbagai cara mulai dari pembentukan ikatan lemah seperti fisik sampai pembentukan ikatan yang relatif kuat seperti pembentukan ikatan kompleks. Interaksi antara ion logam dengan bahan organik alamiah atau buatan dapat melalui mekanisme seperti berikut :1). Gugus karbosiklik dari asam organik membentu garam, 2). Adanya atom donor elektron seper $\mathrm{O}, \mathrm{N}, \mathrm{S}, \mathrm{P}$ yang dapat membentuk ikata koordinasi, 3). Adanya gugus donor elektro phi $(\pi)$ seperti gugus olefinik, cincin aromati (Cotton and Wilkinson, 1989).

Proses adsorpsi ion logam pad biomassa dipengaruhi oleh konsentrasi io logam; waktu interaksi; sifat fisika kimia dar ion logam yang meliputi: kelarutan, ukura molekul dan muatan; temperatur; salinitas; efe kompetisi dengan senyawa lain, $\mathrm{pH}$ maupu kekhasan dan komposisi absorben yan meliputi: kandungan air, kandungan baha organik dan pH (Fisher, 1986; Demon et al 1989)

\section{Pengaruh lama adsorpsi terhadal kemampuan adsorpsi ion besi (II) pad: biomassa Chaetoceros sp.}

Berdasarkan Gambar 1 diketahui bahw waktu adsorpsi maksimum biomass Chaetoceros sp. hasil kultur murni tercapa pada waktu 10 menit sebesar $23 \%$ sedangka hasil pembusukan secara alami tercapai pad waktu 15 menit sebesar $27 \%$. Perbedaan wakt adsorpsi ini disebabkan perbedaan komposis senyawa dalam biomassa.

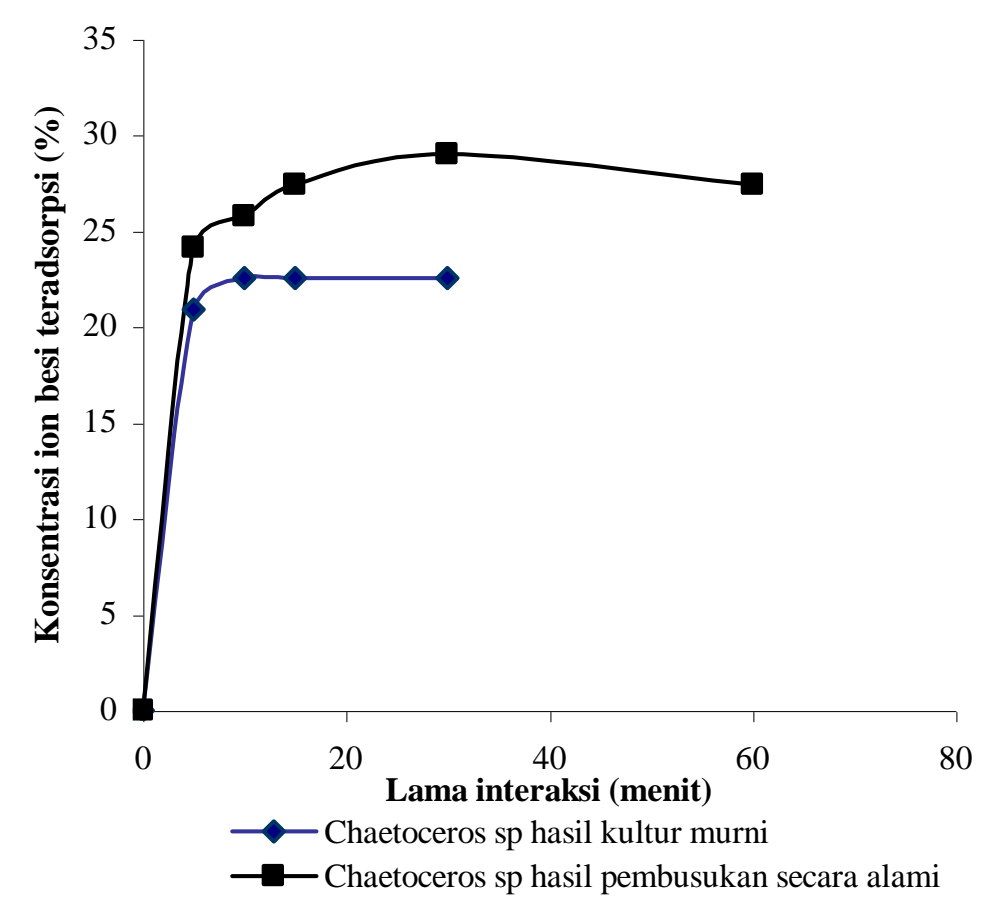

Gambar 1. Pengaruh lama adsorpsi terhadap kemampuan adsorpsi ion besi (II) pada biomassa Chaetoceros sp. 
Menurut Noegrohati dan Narsito (1990) biomassa hasil kultur murni mengandung protein $35 \%$, karbohidrat 6,8\%, lemak 6,9\% dan abu 28\%, karena Chaetoceros sp. termasuk fitoplankton yang dinding selnya tersusun atas zat pektin yang lunak terselubungi zat kersik /silikat $\left(\mathrm{SiO}_{2}\right)$ dengan perbandingan $\mathrm{C}: \mathrm{Si}=2$ : 5, maka abu dari biomassa tersebut terutama tersusun atas silikat, sedangkan tanah diatomae hanya tersusun atas frustule atau kerangka dinding sel terutama terdiri atas silikat $\left(\mathrm{SiO}_{2}\right)$ $86,89 \%$, alumina $\left(\mathrm{Al}_{2} \mathrm{O}_{3}\right) 2,32 \%$, ferri oksida $\left(\mathrm{Fe}_{2} \mathrm{O}_{3}\right)$ 1,28\%, kapur $(\mathrm{CaO}) 0,43 \%$, kalium oksida $\left(\mathrm{K}_{2} \mathrm{O}\right) 3,58 \%$, dengan demikian tanah ini bersifat porous dengan luas permukaan sekitar 0,5-1 $\mathrm{m}^{2} / \mathrm{g}$ (Sahlan, 1978).

Kedua macam biomassa merupakan hasil pembusukan sel mahkluk hidup, sehingga proses adsorpsi yang terjadi secara pasif melalui mekanisme pertukaran kation, kelating, penjerapan ion maupun adsorpsi (Haris and Ramelow, 1990). Kemampuan adsorpsi tanah Diatomae lebih besar dari biomassa kultur murni, hal ini disebabkan perbedaan komposisi kedua biomassa. Tanah diatomae mempunyai jumlah pori lebih besar sehingga adsorpsi melibatkan mekanisme penjerapan ion logam dalam pori, interaksi gugus aktif pada permukaan absorben, yaitu gugus siloksan (SiO) yang bersifat polar serta pertukaran kation dengan melibatkan ion kalsium dan kalium (Stirk and Staden, 2002). Sedangkan kemampuan adsorpsi biomassa kultur murni lebih mengikuti mekanisme kelating dengan melibatkan gugus fungsional senyawa organik seperti: protein, karbohidrat dan lemak sebagai pengompleks, ion exchange dan interaksi gugus aktif siloksan. Dengan demikian peran pori dalam biomassa sangat dominan dalam menentukan kapasitas adsorpsi absorben (Haris and Ramelow, 1990; Stirk and Staden, 2002).

Gambar 2 menunjukkan pengaruh berbagai variasi konsentrasi ion besi (II) terhadap kemampuan adsorpsi biomassa Chaetoceros sp. hasil kultur murni dan pembusukan secara alami. Kemampuan adsorpsi maksimum biomassa hasil kultur murni tercapai pada konsentrasi 5 ppm, sedangkan tanah diatomae tercapai pada konsentrasi $30 \mathrm{ppm}$. Berdasarkan pola kurva adsorpsi pada Gambar 2 terlihat bahwa proses adsorpsi berlangsung dua tahap, yaitu tahap adsorpsi ion besi (II) berlangsung secara cepat dan tahap yang berlangsung secara lambat. Tahap pertama terjadi karena permukaan absorben belum jenuh akan ion besi (II), sedangkan tahap kedua terjadi karena permukaan absorben mulai jenuh ion besi (II) hingga mencapai kejenuhan yang ditandai tercapai adsorpsi maksimum.

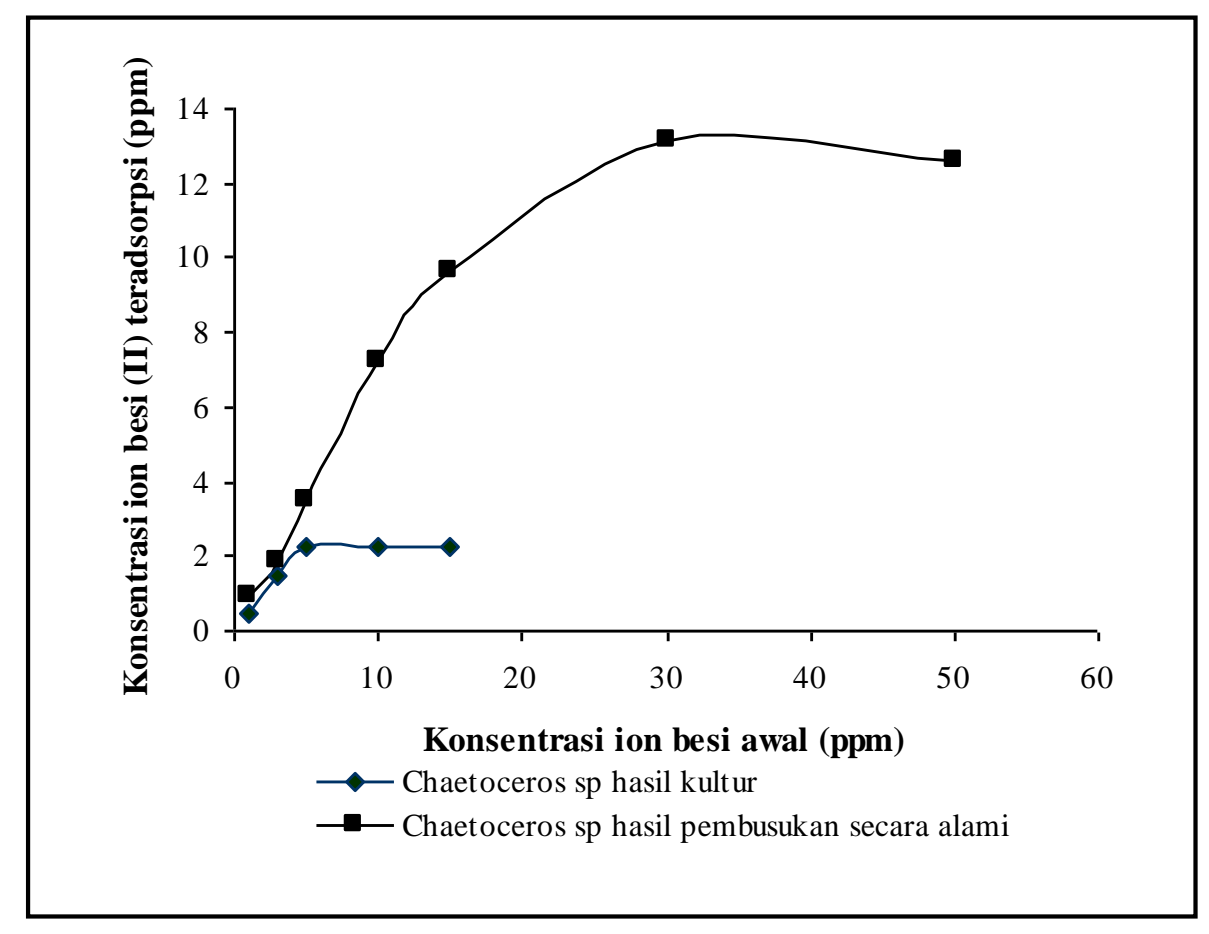

Gambar 2. Kemampuan adsorpsi biomassa Chaetoceros sp. terhadap ion besi (II) diberbagai variasi konsentrasi 
Pola adsorpsi yang terjadi pada kedua biomassa dapat diketahui melalui isoterm Freundlich dan Langmuir. Menurut Freundlich persamaan adsorpsi dinyatakan sebagai berikut:

$$
\mathrm{m}=\mathrm{k} \mathrm{C}^{\mathrm{n}}
$$$$
\log \mathrm{m}=\log \mathrm{k}+\mathrm{n} \log \mathrm{C}
$$

Keterangan:

$\mathrm{m}$ : jumlah mg teradsorpsi pergram absorben

C: konsentrasi pada saat keseimbangan / tidak teradsorpsi

k dan n: konstanta. (Bahl, et al., 2005)

Dengan mengukur $\mathrm{m}$ sebagai fungsi $\mathrm{C}$ dan memplot log $\mathrm{m}$ terhadap $\log \mathrm{C}$, maka harga $\mathrm{n}$ dan $\mathrm{k}$ dapat ditentukan dari slope dan intersep. Isoterm ini dapat menentukan orde dan konstanta adsorpsi serta pola adsorpsi yang terjadi (cenderung multilayer). Isoterm Langmuir dinyatakan sebagai berikut :

$$
\begin{aligned}
\mathrm{m} & =\frac{\mathrm{b} \mathrm{KC}}{1+\mathrm{KC}} \\
\mathrm{C} / \mathrm{m} & =1 / \mathrm{Kb}+1 / \mathrm{b} \mathrm{C}
\end{aligned}
$$

Keterangan:

m:jumlah mg teradsorpsi per gram absorben
C:konsentrasi pada saat keseimbangan/tida teradsorpsi

$\mathrm{K}$ :parameter afinitas adsorpsi yang menyataka kekuatan ikatan/besarnya energi ikata antara zat yang diadsorpsi dan absorben

b:parameter kapasitas yang menyataka kemampuan adsorpsi maksimum absorbe (Bahl et al., 2005).

Parameter $r$ pada model isotern Freundlich dan Langmuir menunjukkan nila korelasi antara variabel terikat dan bebas ternyata pola isoterm adsorpsi pada biomass hasil kultur murni cenderung mengikut isoterm Langmuir, yang berarti pola adsorps yang terjadi cenderung monolayer denga kapasitas adsorpsi maksimum sebesar 95,05 $\mathrm{mg} / \mathrm{g}$ dan energi adsorpsi $129,95 \mathrm{Kal} / \mathrm{mol}$ Berdasarkan besarnya energi yang terliba menunjukkan bahwa interaksi yang terjad antara absorben dengan ion besi (II) sanga lemah, yaitu sebesar ikatan hidrogen atau gay van der waals. Oleh karena itu tipe adsorps yang terjadi fisisorpsi (Sukarjo, 1997; Bahl al., 2005).

Tabel 1. Data isoterm Freundlich dan Langmuir adsorpsi ion besi (II) pada biomassa Chaetoceros sp. hasil kultu murni

\begin{tabular}{ccccc}
\hline \hline $\mathbf{C}(\mathbf{p p m})$ & $\mathbf{m}(\mathbf{m g} / \mathbf{g})$ & $\mathbf{C} / \mathbf{m}$ & $\mathbf{L o g} \mathbf{C}$ & $\mathbf{L o g} \mathbf{m}$ \\
\hline 0.329 & 19.988 & 0.017 & -0.483 & 1.301 \\
1.578 & 59.960 & 0.026 & 0.198 & 1.778 \\
3.077 & 89.932 & 0.034 & 0.488 & 1.954 \\
8.073 & 89.936 & 0.089 & 0.907 & 1.954 \\
13.319 & 89.936 & 0.148 & 1.125 & 1.954 \\
\hline \hline
\end{tabular}

\begin{tabular}{|c|c|c|c|c|}
\hline $\bar{C}$ (ppm) & m (mg/g) & $\mathrm{C} / \mathrm{m}$ & $\overline{L o g} C$ & Log $m$ \\
\hline 0 & 38,184 & $\overline{0}$ & - & 1,582 \\
\hline 0,687 & 75,016 & 0,009 & $-0,163$ & 1,875 \\
\hline 1,490 & 139,320 & 0,011 & 0,173 & 2,144 \\
\hline 3,098 & 289,352 & 0,011 & 0,491 & 2,461 \\
\hline 6,045 & 385,800 & 0,016 & 0,781 & 2,586 \\
\hline 17,833 & 525,116 & 0,034 & 1,251 & 2,720 \\
\hline 36,588 & 503,684 & 0,073 & 1,563 & 2,702 \\
\hline
\end{tabular}

Tabel 2. Parameter isoterm Freundlich dan Langmuir pada biomassa Chaetoceros sp. hasil kultur murni

\begin{tabular}{ccccccc}
\hline \hline & Isoterm Freundlich & \multicolumn{4}{c}{ Isoterm Langmuir } \\
\hline $\mathrm{r}$ & $\mathrm{k}$ & $\mathrm{n}$ & $\mathrm{r}$ & $\mathrm{K}$ & $\mathrm{b}(\mathrm{mg} / \mathrm{g})$ & $\mathrm{E}(\mathrm{Kal} / \mathrm{mol})$ \\
\hline 0.919 & 40.429 & 0.412 & 0.997 & 1.238 & 95.057 & 129.95 \\
\hline \hline
\end{tabular}

Tabel 3. Data isoterm Freundlich dan Langmuir adsorpsi ion besi (II) pada biomassa Chaetoceros sp. has pembusukan secara alami 
Hal yang sama, ditunjukkan pada hasil pola adsorpsi tanah diatomae juga mengikuti isoterm Langmuir, yang berarti isoterm monolayer dengan kapasitas adsorpsi maksimum sebesar $550,812 \mathrm{mg} / \mathrm{g}$ dan energi adsorpsi $-592,14 \mathrm{Kal} / \mathrm{mol}$. Berdasarkan besarnya energi yang terlibat menunjukkan ikatan yang terjadi antara ion besi (II) dengan biomassa termasuk fisisorpsi (Sukarjo,1997).

\section{Pengaruh pH pada kemampuan adsorpsi biomassa Chaetoceros sp. terhadap ion besi (II)}

Tingkat kelarutan ion besi (II) dipengaruhi oleh $\mathrm{pH}$ larutan (Stirk and Staden, 2002; Deleebeeck et al., 2005). Menurut Stary et al, (1983), Nugroho dan Sucahyo (2000), dan Slaveykova and Wilkinson (2002), di dalam linglkungan perairan kelarutan logam pada prinsipnya diatur oleh: 1) $\mathrm{pH}, 2$ ) jenis dan konsentrasi ligan dan zat pengkelat, 3) tingkat oksidasi komponen mineral dan lingkungan redoks sistem perairan tersebut.

Menurut Deleebeeck et al., (2005); Stirk and Staden, (2002), bahwa kemampuan adsorpsi ion besi (II) pada pemukaan situs aktif biomassa berkurang disebakan adanya 1). pengendapan ion logam, 2) proses hidrolisis logam, 3) pengendapan spesies hasil hidrolisis, 4) kompetisi antara ion logam dengan proton pada situs aktif absorben, 5) perubahan muatan gugus aktif permukaan. Gambar 3 menunjukkan kemampuan adsorpsi biomassa Chaetoceros sp. hasil kultur murni terhadap ion besi (II) pada berbagai variasi $\mathrm{pH}$ dari 0,5 sampai 10. Secara umum dapat dinyatakan bahwa kemampuan adsorpsi biomassa terhadap ion besi (II) meningkat seiring dengan bertambahnya $\mathrm{pH}$ larutan. Adsorpsi maksimum terjadi pada $\mathrm{pH}$ sekitar 5 sedangkan $\mathrm{pH}$ di atas 5 tidak terjadi peningkatan secara signifikan.

Chaetoceros sp. merupakan fitoplankton dengan dinding sel tersusun atas senyawa silika, yang memiliki gugus aktif siloksan $(\mathrm{SiO})$ yang bersifat polar, mengandung protein yang bersifat bipolar dan karbohidrat yang mempunyai gugus fungsi polar. Pada $\mathrm{pH}$ di atas 5, permukaan Chaetoceros sp. praktis mempunyai muatan negatif sehingga memiliki kemampuan menyerap ion logam lebih besar, sedangkan pada $\mathrm{pH}$ di bawah 5 situs aktif pada absorben bermuatan positif sehingga kemampuan mengadsorpsi ion besi semakin berkurang dengan semakin rendahnya $\mathrm{pH}$, selain itu dengan menurunnya $\mathrm{pH}$ larutan menyebabkan terjadi persaingan yang cukup ketat antara ion besi (II) dengan ion hidrogen (proton) (Stirk and Staden, 2002; Deleebeeck et al., 2005).

Secara alamiah ion besi yang dapat diadsorpsi oleh biomassa adalah dalam bentuk kation terhidrat, yaitu bentuk molekul dalam kondisi terkomplekskan secara ikatan koordinasi (Muljopawiro, 2000). Kenaikan pH larutan dapat meningkatkan konsentrasi ion hidroksida, sehingga menurunkan konsentrasi ion besi dalam larutan. Dengan demikian dapat dikatakan bahwa meningkatnya $\mathrm{pH}$ dapat membuat permukaan situs aktif absorben bermuatan negatif, mengubah bilangan oksidasi ion besi (II) menjadi besi (III) serta dapat mengendapkan ion besi (menurunkan kelarutan).

Cotton dan Wilkinson (1989), Shriver et al., (1990), dan Ledin et al., (1997) menyatakan bahwa ion besi dalam kondisi larutan asam ( $\mathrm{pH}$ 2-3) terhidrolisis secara sempurna membentuk $\left[\mathrm{Fe}\left(\mathrm{H}_{2} \mathrm{O}\right)\right]^{2+}$. Kenaikan $\mathrm{pH}$ 2-3 terjadi kondensasi ion besi terhidrat membentuk spesies dinuklir, sedangkan $\mathrm{pH}$ di atas tersebut menyebabkan terbentuknya hidroksida logam $\left[\mathrm{Fe}(\mathrm{OH})_{2}\right]$ yang berupa kristal. Oleh karena itu dari data Gambar $3 \mathrm{pH}$ di atas 5 yang diperkirakan sekitar $100 \%$ ion logam besi teradsorpsi oleh biomassa adalah tidak tepat, namun secara jelas dapat diungkapkan bahwa meningkatnya $\mathrm{pH}$ larutan dapat memperbesar kemampuan adsorpsi ion besi pada biomassa sejauh tidak terjadi penurunan tingkat kelarutan ion tersebut, hal ini dikarenakan semakin tingginya $\mathrm{pH}$ larutan menyebabkan situs permukaan absorben bermuatan negatif. Hasil ini mendukung penelitian dari Ledin et al., (1997) tentang efek $\mathrm{pH}$ terhadap adsopsi logam oleh organisma. 
Paini Sri Widyawati

Tabel 4. Parameter isoterm Freundlich dan Langmuir pada biomassa Chaetoceros sp. hasil pembusukan secara alami

\begin{tabular}{ccccccc}
\hline \hline & Isoterm Freundlich & \multicolumn{4}{c}{ Isoterm Langmuir } \\
\hline \hline $\mathrm{r}$ & $\mathrm{k}$ & $\mathrm{N}$ & $\mathrm{r}$ & $\mathrm{K}$ & $\mathrm{b}(\mathrm{mg} / \mathrm{g})$ & $\mathrm{E}(\mathrm{Kal} / \mathrm{mol})$ \\
\hline 0.938 & 121,941 & 0.469 & 0.992 & 0,378 & 550,812 & $-592,14$ \\
\hline \hline
\end{tabular}

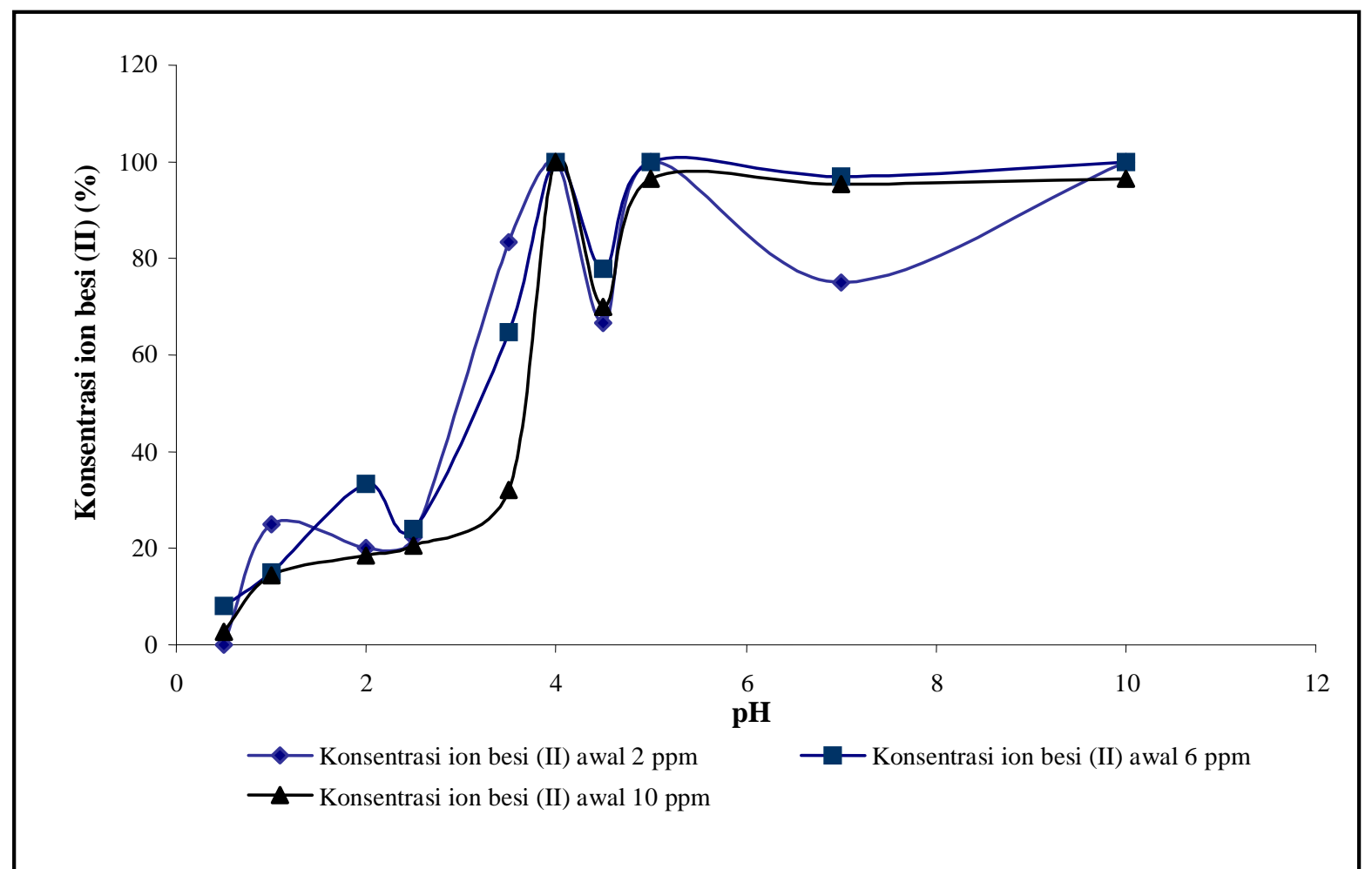

Gambar 3. Pengaruh $\mathrm{pH}$ terhadap kemampuan adsorpsi ion besi (II) pada biomassa Chaetoceros sp. hasil kultur murni diberbagai variasi konsentrasi

\section{Kesimpulan}

Proses adsorpsi oleh biomassa Chaetoceros sp. berlangsung sangat cepat, dan lebih cepat dibandingkan waktu adsorpsi maksimum biomassa Chaetoceros sp. Namun pola adsorpsi biomassa Chaetoceros sp. terhadap ion besi (II) bersifat monolayer dengan mengikuti isoterm Langmuir dan terjadi secara fisik. Kemampuan Chaetoceros sp. menyerap ion besi (II) lebih cepat tetapi lebih kecil dibandingkan tanah diatomae. Kemampuan menyerap ion besi (II) oleh Chaetoceros sp. meningkat dengan peningkatan $\mathrm{pH}$.

\section{Daftar Pustaka}

Aderhold, D., Williams, C.J. and Edyvean, R.G.J. 1996. The Removal of Heavy Metal Ions by Seaweeds and Their Derivatives. Biores. Technol. $58: 1-6$.
Bahl, B.S., Bahl, A. and Tuli, G.D. 2005. Adsorption. Ir Essential of Physical Chemistry. S. Chand $d$ Company Ltd. Ram Nagar-New Delhi.

Cotton and Wilkinson. 1989. Kimia Anorganik Dasar. U Press. Jakarta.

Cossich, E.S., Tavares, C.R.G. and Ravagnani, T.M.K 2001. Biosorption of Chromium (III) b Sargassum sp Biomass. Electronic Journal c Biotechnology. 5(2) : 1-7.

Deleebeeck, N.M.E., Scamphelaere, K.A.C. and Jansser C.R. 2005. The Effect of $p H$ on The Toxicit of Ni to the Green Alga Pseudokirchneriell subcapitata. Lab. Of Environment: Toxicology and Chemistry. Belgium.

Demon, A., Debruin, M. and Wolterbeek. 1989. Th Influence of Pre-Treatment, Temperature an Calcium Ions Trace Element Uptake by a Alga (Scenedesmus ponnonicus Sub Berlin) and Fungus (Aureobasidiur pullulans). Environmental Monitoring an Assessment. $13:$ 21-33.

Fisher, N.S. 1986. Marine Plankton Food Chain Ann.Rev.Ecol.Sys. 19 : 19-38. 
Kinetika Adsorpsi Ion Besi

Hamdy, A.A. 2000. Biosorption of Heavy Metals by Marine Algae. Curr.Microbiol. 41(4) : 232238.

Harris, P.O. and Ramelow, G.J. 1990. Binding of Metal Ions by Particulate Biomass Derivated from Particulate Biomass Derivated from Chlorella vulgaris and Scenedismus quadricauda. Environ. Sci. Technol. $24: 2$.

Hassler, C.S., Slaveykova, V.I. and Wilkinson, K.J. 2004. Discriminating between Intra- and Extracellular Metals Using Chemical Extractions. Limnol. Oceanogr. Methods. 2 : 237-247.

Ledin, M., Pedersen, K. and Allard, B. 1997. Effects of $\mathrm{pH}$ and Ionic Strength on the Adsorption of $\mathrm{Cs}, \mathrm{Sr}, \mathrm{Eu}, \mathrm{Zn}$ and $\mathrm{Hg}$ by Pseudomonas putida. Water, Air and Soil Pollution. 93 : 367-381.

Muljopawiro, S. 1998. Ketersediaan Besi Hayati Dalam Sayuran Diukur Secara in Vitro. Biota III (2): 34-43.

Noegrohati, S. and Narsito. 1990. Bioindikator Pencemaran Laut. Laporan Penelitian. UGM. Yogyakarta.

Nugroho, R.A. dan Sucahyo. 2000. Uji Ekotoksisitas Seng (Zn) terhadap Ikan Seribu (Poecilia reticulta Peters.) Biota V(2) : 81-85.
Sahlan, M. 1978. Planktonologi. Dirjen Perikanan. Jakarta.

Shriver, D.F., Atkins, P.W. and Langford, C.H. 1990 Inorganic Chemistry. Oxford University Press. Oxford.

Slaveykova, V.I. and Wilkinson, K.J. 2002. Physicochemical Aspects of Lead Bioaccumulation by Chlorella vulgaris. Environ. Sci. Technol. 36 : 969-975.

Stary, J., Karatzer, K. and Prasilova, J. 1983. The Cumulation of Alkali Earths and Alkali Metals on Alga. Intern. J. Environ. Anal. Chem. 14 : 161-167.

Stirk, W.A. and Staden, J.V. 2002. Desorption of Cadmium and the Reuse of Brown Seaweed Derived Products as Biosorbents. Botanica Marina. 45 : 9-16.

Sukarjo. 1997. Kimia Físika (eds. 3rd). PT Rineka Cipta. Jakarta.

Thakur, D.N. 2001. Fundamental Concept in Physical Chemistry (eds. 1st). S.Chand and Company LTD. New Delhi. 